\title{
Pre-harvest Treatments to Reduce Incidence of the Soft Scald and to Enhance Coloration of "Anna" Apple Fruits
}

\author{
Karim M. Farag and *Said M. Attia \\ Horticulture Department (Pomology), Faculty of Agriculture, Damanhour University, Egypt. \\ *Email: said.attia@agr.dmu.edu.eg
}

Received on: $14 / 5 / 2018$

Accepted for publication on: $21 / 5 / 2018$

\section{Abstract:}

Few attempts have been made to overcome problem of the soft scald. Many factors and conditions are associated with such physiological disorder. In this study, seven-years-old "Anna" apple trees were preharvest sprayed during 2016 and 2017 growing seasons with lisophos $1000 \mathrm{mg} /$ litre, potassium sulphate $2 \%$, calcium sulphate $2 \%$ and their combinations in order to investigate their influence on initiation of the soft scald and fruit quality especially fruit coloration at harvest as well as keeping fruit quality during storage for seven days on refrigerator. Lisophos alone or plus either calcium sulphate or potassium sulphate reduced initiation of the soft scald at harvest as compared with untreated fruits, in addition to retarding the loss of fruit firmness. The application of potassium sulphate alone or incorporated with lisophos treatment increased fruit diameter, fruit TSS, total sugars, peel anthocyanin and carotene contents but decreased fruit acidity, peel chlorophyll $\mathrm{a}$ and $\mathrm{b}$ as compared with control. After seven days of refrigerated shelf life, the application of lisophos plus calcium sulphate retarding the loss of flesh firmness, reduced weight loss $\%$ and incidence of the soft scald percentage. This study provided evidences about the possibility of reducing incidence of the soft scald in "Anna" apples by preharvest application of lisophos plus either calcium sulphate or potassium sulphate, while, enhancing fruit quality and coloration.

Keywords: Soft Scald-Apple Fruits- Lisophos- Pre-harvest-Calcium- Potassium- Storage-Anthocyanin.

\section{Introduction}

Soft scald of apple fruit is a physiological disorder that causes serious losses for growers in many countries especially after harvest (Johnston et al., 2002a). The symptoms of soft scald are soft brown lesion on the skin of the apple which extends into the flesh (DeEll, 2009). There were many factors affecting apple softening before and after harvest which also hasten the respiration climacteric rise apples including temperature during fruit growth especially warmer temperature (Bramlage, 1993: Emongor et al., 1994).
There has been a lack for more research effort to overcome this problem or to alleviate the possible causes. The available data indicated to the involvement of many factors and conditions that lead to the incidence of soft scald such as late harvest or advanced maturity, mineral nutrition, light crop load, large fruit and vigorous trees (Snowdon, 1990). More the ethylene content in apple fruits after harvest more the incidence of soft scald (Farag, 2006). This disorder is also correlated with storage conditions (Johnston et al., 2002b). In addition, ethylene treatments which 
induce softening in apples by regulating expression of cell wall modifying enzymes such as polygalacturonase (Atkinson et al., 1998).

Good colors of apple fruit without physiological disorder determinants the value of many apple cultivars. Skin coloration of apples is directly related to the anthocyanin pigments (Lancaster et al., 1994: Li et al., 2008) or carotenes in some other cultivars. These pigments provide essential cultivar differentiation for consumers and are implicated in the health attributes of apple fruit including their roles as antioxidants. Under Egypt climatic conditions, "Anna" apple fruit has tendency not to develop good red color. Poor coloration has been a serious problem in affecting growers profit from these cultivars (Boyer and Liu, 2004).

Lysophosphatidylethanolamine

(LPE) such as lisophos is a natural lipid has been used as a coloring and ripening agent in many fruit crops such as apple, cranberry, tomato and plum (Farag and Palta, 1989, 1992 and Farag and Attia, 2016) while keeping fruit quality by either lowering the respiration rate, inhibiting the activity of cell wall hydrolyses and by retarding senescence (Farag and Palta, 1993). On the other hand, calcium plays an important role in maintaining the quality and storability of fruit (Bhat et al., 2012: Wehr et al., 2004). Calcium-treated apple fruit have less disruption and degradation of the pectin-rich middle lamella, and have more cell-to-cell contact than non-treated fruit (Glenn and Poovaiah, 1990). Adequate levels of calcium are necessary for normal membrane function (Jaleel et al., 2007).

Potassium is one of the essential nutrients described as the quality element for fruit crop production. It wasreported to improve fruit quality, fruit coloration, shipping quality and shelf life (Lester et al., 2007). Preharvest application of potassium sulphate positively enhanced physical and chemical quality of many fruit species such as apples, grapes, nectarines and guava (Nava et al., 2007; Anjum et al., 2008; Gill et al., 2012; Yang et al., 2008). Soares et al. (2005) showed that preharvest application of potassium on pineapple fruit reduced internal browning physiological disorder.

Aforementioned, the objectives of this study were to investigate the effect of preharvest spray of lisophos, calcium sulphate and potassium sulphate on the incidence of soft scald disorder and to enhance coloration of "Anna" apple fruits.

\section{Materials and Methods}

\section{1- Experimental design:}

The present study was conducted during two seasons, 2016 and 2017 on seven-years-old "Anna" apple trees (Malusdomestica L). The description of the experiment was recorded in Table (1).

\begin{tabular}{|c|c|c|c|c|c|}
\hline Cultivar & Rootstock & Study location & $\begin{array}{c}\text { Irrigation } \\
\text { system }\end{array}$ & Soil type & $\begin{array}{c}\text { Distance be- } \\
\text { tween trees }\end{array}$ \\
\hline Anna & Balady & $\begin{array}{c}\text { Private orchard at Elboustan } \\
\text { region, Emam Huseinyvil- } \\
\text { lage, Behira, Egypt. }\end{array}$ & $\begin{array}{c}\text { Drip irri- } \\
\text { gation }\end{array}$ & Sandy soil & $4 \times 4 \mathrm{~m}$ \\
\hline
\end{tabular}


The study layout was randomized complete block design (RCBD) and the following seven foliar treatments were carried out with three replicates for each treatment and one tree represented one replication;

1- Untreated trees (sprayed water only as control).

2- Lisophos at $1000 \mathrm{mg} / \mathrm{L}$ (Phospholipid 70\%).

3- Potassium Sulphate (PS) at $2 \%$.

4- Calcium Sulphate (CS) at $2 \%$.

5- Lisophos + Potassiumsulphate.

6- Lisophos + Calciumsulphate.

7- Potassiumsulphate+ Calciumsulphate.

The trees received the treatments once application time during 11, 7 June through 2016 and 2017, respectively. The surfactant Top film was added to all treatments at the rate of $0.5 \mathrm{~cm}^{3} /$ litre solution. The trees were sprayed directly with treatments solution with hand pump sprayer to runoff in the morning.

\section{analyses:}

\section{2- Physical and chemical}

At harvest, a sample of 10 fruits of each replicate was randomly selected in both seasons to determine the following characteristics:

Fruit weight $(\mathrm{g})$, fruit volume $\left(\mathrm{cm}^{3}\right)$, fruit diameter $(\mathrm{cm})$ and fruit length $(\mathrm{cm})$, fruit firmness $\left(\mathrm{Ib} / \mathrm{inch}^{2}\right)$ was recorded using Effigi pressure tester (mod. FT 327) scale of, 3-27 Lbs. and incidence of the soft scald was visually estimated. Moreover, in fruit juice, percentage of the total soluble solids (TSS\%) was measured by a hand refractometer, titratableacidity as grams of malic acid per $100 \mathrm{~g}$ juice was determined by titration with $0.1 \mathrm{~N} \mathrm{NaOH}$ according to
AOAC (1985) and TSS/Acidity ratio was estimated. Fruit total sugars were extracted from the fruit according to (Egan et al., 1981) and total sugars were determined calorimetrically using phenol sulphuric acid method according to(Smith, 1956). In addition, chlorophyll a, b and carotene were determined according to (Lichtenthaler and Wellburn, 1985), Anthocyanin was determined according to Fuleki and Francis (1968) while Lascorbic acid was determined according to AOAC (1985).

\section{3- Shelf life assessment:}

In order to investigate the effect of the different treatments on the development of soft scald, physical and chemical characteristics of apples, a sample of five fruits from each replicate was kept at refrigerator at (4 $5 \mathrm{C}^{\circ}$ ) for seven days. Then, fruits were put at room temperature $\left(20 \pm 2 \mathrm{C}^{\circ}\right)$ for two days to determine the development of incidence of the soft scald. Fruit weight loss $\%$, fruit firmness, $\mathrm{TSS} \%$, acidity $\%$, also, total sugars $\%$, L-ascorbic acid, chlorophylls a, b, carotenes and anthocyanin were determined by using the same aforementioned methods and procedures.

\section{4- Statistical analysis:}

The investigation was analyzed using Statistical Analysis System (SAS, 2000). Treatments were arranged in a randomized complete block design (RCBD). Three replications were used with each treatment and one tree represented one replication. The least significant differences (LSD) at 0.05 levels according to Sendecor and Cochran (1980) were used to compare treatments means. 


\section{Results}

The effect of preharvest treatments with some safe compounds such as lisophos, potassium and calcium sulphate or their combinations on incidence of the soft scald disorder in "Anna" apples was reported in Table 2. Data indicated reduction in the percentage of the soft scald at the harvest time with varying degrees of efficacy. The least value was obtained by the combination of lisophos plus calcium sulphatein both seasons ranging between 10.0 to $11.7 \%$ while the highest incidence of soft scald occurred in the control ranging between $23.3 \%$ to $26.7 \%$ in the two studied seasons, respectively. Meanwhile, many other applications were also successful in reducing soft scald comparing with the control. It seemed that the presence of calcium sulphateas single treatment or when combined with lisophos was necessary to minimize the incidence of soft scald in "Anna" apples in a consistent manner in both seasons. Meanwhile, flesh firmness was also significantly influ- enced by various used treatments as reported in Table 2. The data revealed that the greatest flesh firmness of "Anna" apples was obtained again with the combination of calcium sulphateplus lisophos as compared with the control (Table 2). Even when either lisophos or calcium sulphate was solely used each one of them was able to retard the loss of flesh firmness relative to the control while potassium sulphate actually caused a significant reduction in flesh firmness relative to the control in both seasons. However, combination of both compounds with lisophos, resulted in greater flesh firmness than that found with the sole application of potassium sulphate alone. Thus, the inclusion of lisophos in the treatment solution was able to mitigate the adverse influence of potassium sulphate on "Anna" apples in both seasons. When both potassium and calcium sulphates were applied as single solution induced no significant influence on flesh firmness in a consistent manner in both seasons.

Table 2. Effect of pre-harvest treatments of lisophos, potassium sulphate and calcium sulphate on soft scald percentage and flesh firmness of "Anna" apples at harvest during 2016 and 2017 , seasons.

\begin{tabular}{|c|c|c|c|c|}
\hline \multirow[b]{2}{*}{ Treatments } & \multicolumn{2}{|c|}{ Season 2016} & \multicolumn{2}{|c|}{ Season 2017} \\
\hline & Soft scald (\%) & $\begin{array}{l}\text { Flesh firmness } \\
\left(\mathrm{Ib} / \mathrm{inch}^{2}\right)\end{array}$ & Soft scald $(\%)$ & $\begin{array}{c}\text { Flesh firmness } \\
\left(\text { Ib/ inch }{ }^{2}\right)\end{array}$ \\
\hline Control (water only) & $23.33 \mathrm{a}$ & $9.03 \mathrm{~d}$ & $26.67 \mathrm{a}$ & $8.70 \mathrm{de}$ \\
\hline Lisophos at $1000 \mathrm{mg} / \mathrm{L}$ & $13.33 \mathrm{bc}$ & $9.40 \mathrm{c}$ & $15.00 \mathrm{bc}$ & $9.23 \mathrm{ab}$ \\
\hline Potassium Sulphate (PS) at $2 \%$ & $16.67 \mathrm{~b}$ & $8.60 \mathrm{e}$ & $18.33 \mathrm{~b}$ & $8.57 \mathrm{e}$ \\
\hline Calcium Sulphate $(\mathrm{CS})$ at $2 \%$ & $11.67 \mathrm{bc}$ & $9.93 \mathrm{~b}$ & $13.33 \mathrm{bc}$ & $9.07 \mathrm{bc}$ \\
\hline Lisophos +Potassium Sulphate & $13.33 \mathrm{bc}$ & $9.10 \mathrm{~d}$ & $16.67 \mathrm{bc}$ & $8.93 \mathrm{~cd}$ \\
\hline Lisophos + Calcium Sulphate & $10.00 \mathrm{c}$ & $10.23 \mathrm{a}$ & $11.67 \mathrm{c}$ & $9.47 \mathrm{a}$ \\
\hline Potassium Sulphate + Calcium Sulphate & $13.33 \mathrm{bc}$ & $9.22 \mathrm{~cd}$ & $16.67 \mathrm{bc}$ & $8.93 \mathrm{~cd}$ \\
\hline
\end{tabular}

*Values, within each column, of similar letter (s) were not significantly different according to the least significant difference (LSD) at 0.05 levels.

Regard to the influence of various preharvest field applications on some physical characteristics of "Anna" apples, the data reported in
Table 3 revealed that there was no significant alteration in fruit weight due to all used treatments in both seasons. Consequently, that was also the 
general trend for fruit size in both seasons except with fruit size in the second season that was significantly increased relative to the control by the application of potassium sulphate. A typical trend of results was found for fruit length of "Anna" apples that was similar for all treatments and the control except with an increase obtained with potassium sulphate in the second season as compared with the control (Table 3). In addition, fruit diameter was not significantly affected by various applied treatments in both seasons except with the application of potassium sulphate that resulted in a significant increase in fruit diameter in both seasons when compared with the control.

Table 3. Effect of pre-harvest treatments of lisophos, potassium sulphate and calcium Sulphate on some physical characteristics of "Anna" apples at harvest during 2016 and 2017, seasons.

\begin{tabular}{|c|c|c|c|c|c|c|c|c|}
\hline \multirow[b]{2}{*}{ Treatments } & \multicolumn{2}{|c|}{ Season 2016} & \multicolumn{2}{|c|}{ Season 2017} & \multicolumn{2}{|c|}{ Season 2016} & \multicolumn{2}{|c|}{ Season 2017} \\
\hline & $\begin{array}{c}\text { Fruit } \\
\text { weight } \\
\text { (g) }\end{array}$ & $\begin{array}{c}\text { Fruit } \\
\text { size } \\
\left(\mathrm{cm}^{3}\right)\end{array}$ & $\begin{array}{c}\text { Fruit } \\
\text { weight } \\
\text { (g) }\end{array}$ & $\begin{array}{c}\text { Fruit } \\
\text { size } \\
\left(\mathrm{cm}^{3}\right)\end{array}$ & $\begin{array}{l}\text { Fruit } \\
\text { length } \\
(\mathrm{cm})\end{array}$ & \begin{tabular}{|c|} 
Fruit \\
diameter \\
$(\mathrm{cm})$
\end{tabular} & $\begin{array}{l}\text { Fruit } \\
\text { length } \\
(\mathbf{c m})\end{array}$ & \begin{tabular}{|c|} 
Fruit \\
diameter \\
$(\mathrm{cm})$
\end{tabular} \\
\hline Control (water only) & $132.79 \mathrm{~ns}$ & $142.01 \mathrm{~ns}$ & $137.31 \mathrm{~ns}$ & $140.02 \mathrm{~b}$ & $6.49 \mathrm{~ns}$ & $6.09 \mathrm{bc}$ & $6.84 \mathrm{~b}$ & $6.14 \mathrm{~b}$ \\
\hline Lisophos at $1000 \mathrm{mg} / \mathrm{L}$ & $135.35 \mathrm{~ns}$ & $138.92 \mathrm{~ns}$ & $138.88 \mathrm{~ns}$ & $142.27 \mathrm{ab}$ & $7.12 \mathrm{~ns}$ & $6.00 \mathrm{c}$ & $6.86 \mathrm{~b}$ & $6.20 \mathrm{ab}$ \\
\hline Potassium Sulphate (PS) at $2 \%$ & $144.56 \mathrm{~ns}$ & $140.55 \mathrm{~ns}$ & $140.49 \mathrm{~ns}$ & $149.32 \mathrm{a}$ & $7.14 \mathrm{~ns}$ & $6.33 \mathrm{a}$ & $6.59 \mathrm{ab}$ & $6.25 \mathrm{a}$ \\
\hline Calcium Sulphate $(\mathrm{CS})$ at $2 \%$ & $145.05 \mathrm{~ns}$ & $146.63 \mathrm{~ns}$ & $139.34 \mathrm{~ns}$ & $143.06 \mathrm{ab}$ & $7.00 \mathrm{~ns}$ & $6.23 \mathrm{ab}$ & $7.06 \mathrm{a}$ & $6.21 \mathrm{ab}$ \\
\hline Lisophos +Potassium Sulphate & $140.63 \mathrm{~ns}$ & $142.81 \mathrm{~ns}$ & $140.70 \mathrm{~ns}$ & $143.29 \mathrm{ab}$ & $7.00 \mathrm{~ns}$ & $6.04 \mathrm{bc}$ & $6.90 \mathrm{ab}$ & $6.16 \mathrm{ab}$ \\
\hline Lisophos + Calcium Sulphate & $138.37 \mathrm{~ns}$ & $145.13 \mathrm{~ns}$ & $137.41 \mathrm{~ns}$ & $141.61 \mathrm{ab}$ & $6.76 \mathrm{~ns}$ & $6.18 \mathrm{abc}$ & $6.90 \mathrm{ab}$ & $6.16 \mathrm{ab}$ \\
\hline Potassium Sulphate + Calcium Sulphate & $138.11 \mathrm{~ns}$ & $140.27 \mathrm{~ns}$ & $137.39 \mathrm{~ns}$ & $142.13 \mathrm{ab}$ & $6.84 \mathrm{~ns}$ & $6.00 \mathrm{c}$ & $6.95 \mathrm{ab}$ & $6.21 \mathrm{ab}$ \\
\hline
\end{tabular}

*Values, within each column, of similar letter (s) were not significantly different according to the least significant difference (LSD) at 0.05 levels.

Furthermore, the effect of applied treatments before harvest on some chemical characteristics of "Anna" apples was reported in Table 4. It was evident that total soluble solids (TSS) were increased by many treatments especially those that included lisophos either alone or when combined with potassium sulphate or plus calcium sulphate. However, calcium Sulphate alone was not able to cause a significant change in TSS\% as compared with the control in both seasons, while potassium sulphate resulted in a significant increase in $\mathrm{TSS} \%$ either alone or when combined with calcium sulphate. On the other hand, total acidity\% in "Anna" apples juice was significantly reduced relative to the control by all lisophos sprayed either alone or as combina- tion with either potassium sulphate or calcium sulphate. However, the individual application of calcium sulphate resulted in similar total acidity in apple juice that found in the control as well as its combination with potassium sulphate in both seasons. Even the application of potassium sulphate alone caused a reduction in fruit acidity $\%$ similar to that obtained by lisophos. Meanwhile the TSS to acidity ratio was significantly affected by many treatments whether individually as the case with lisophos or potassium sulphateor in combinations as occurred with the application of lisophos plus potassium sulphate or plus calcium sulphate. However, calcium sulphate again was not able to increase such ratio as compared with the control consistently. Regard- 
ing to total sugars $\%$ the data in Table 4 indicated that all applied treatments resulted in total sugars $\%$ relative to the control with greater magnitude of increase as with lisophos alone, potassium sulphate alone or their combination in both seasons. Even the combination of potassium sulphate plus calcium sulphate was able to cause a significant increase in total sugars $\%$ as compared with the control
(Table 4). The changes in vitamin $\mathrm{C}$ in response to various applied treatments seemed to take a different trend since potassium sulphate alone or its combination with lisophos were not effective in increasing vitamin $\mathrm{C}$ content. However, the significant increase in vitamin $\mathrm{C}$ was obtained with either lisophos solely or its combination with calcium sulphatein both seasons (Table 4).

Table 4. Effect of pre-harvest treatments of lisophos, potassium sulphate and calcium sulphate on some chemical characteristics of "Anna" apples during 2016 and 2017 , seasons.

\begin{tabular}{|c|c|c|c|c|c|c|c|c|c|c|}
\hline \multirow[b]{2}{*}{ Treatments } & \multicolumn{2}{|c|}{$\begin{array}{c}\text { Season } \\
2016 \\
\end{array}$} & \multicolumn{2}{|c|}{$\begin{array}{c}\text { Season } \\
2017 \\
\end{array}$} & \multicolumn{2}{|c|}{$\begin{array}{c}\text { Season } \\
2016\end{array}$} & \multicolumn{2}{|c|}{$\begin{array}{c}\text { Season } \\
2017\end{array}$} & \multirow{2}{*}{\begin{tabular}{|c|}
$\begin{array}{c}\text { Season } \\
2016\end{array}$ \\
Vitamin \\
$\mathrm{C}$ \\
$\mathrm{mg} / 100 \mathrm{~g}$
\end{tabular}} & \multirow{2}{*}{\begin{tabular}{|c|c}
$\begin{array}{c}\text { Season } \\
2017\end{array}$ \\
Vitamin \\
$\mathrm{C}$ \\
$\mathrm{mg} / \mathbf{1 0 0 g}$
\end{tabular}} \\
\hline & $\begin{array}{l}\text { TSS } \\
\text { (\%) }\end{array}$ & $\begin{array}{c}\text { Acidity } \\
(\%)\end{array}$ & TSS (\%) & $\begin{array}{c}\text { Acidity } \\
(\%)\end{array}$ & $\begin{array}{c}\text { TSS/ } \\
\text { Acidity } \\
\%\end{array}$ & $\begin{array}{c}\text { Total } \\
\text { sugar } \\
\%\end{array}$ & $\begin{array}{c}\text { TSS/ } \\
\text { Acidity } \\
\%\end{array}$ & \begin{tabular}{|c|} 
Total \\
sugar \\
$\%$
\end{tabular} & & \\
\hline Control (water only) & $13.60 \mathrm{c}$ & $1.01 \mathrm{a}$ & $13.80 \mathrm{~d}$ & $0.98 \mathrm{a}$ & $13.53 \mathrm{~d}$ & $8.13 \mathrm{e}$ & $14.11 \mathrm{e}$ & $8.90 \mathrm{~g}$ & $5.66 \mathrm{c}$ & $5.33 \mathrm{~d}$ \\
\hline Lisophos at $1000 \mathrm{mg} / \mathrm{L}$ & $15.10 \mathrm{a}$ & $0.81 \mathrm{c}$ & $15.20 \mathrm{~b}$ & $0.79 \mathrm{c}$ & $18.98 \mathrm{a}$ & $9.16 \mathrm{a}$ & $19.23 \mathrm{~b}$ & $9.82 \mathrm{c}$ & $7.02 \mathrm{~b}$ & $7.23 \mathrm{~b}$ \\
\hline Potassium Sulphate (PS) at 2\% & $15.10 \mathrm{a}$ & $0.80 \mathrm{c}$ & $15.40 \mathrm{ab}$ & $0.77 \mathrm{c}$ & $18.78 \mathrm{a}$ & $9.09 \mathrm{a}$ & $19.82 \mathrm{ab}$ & $9.99 \mathrm{~b}$ & $5.27 \mathrm{c}$ & $5.14 \mathrm{~d}$ \\
\hline Calcium Sulphate $(\mathrm{CS})$ at $2 \%$ & $13.90 \mathrm{c}$ & $0.99 \mathrm{a}$ & $14.00 \mathrm{~d}$ & $0.98 \mathrm{a}$ & $14.02 \mathrm{~cd}$ & $8.41 \mathrm{~d}$ & $14.32 \mathrm{de}$ & $9.04 \mathrm{f}$ & $9.10 \mathrm{a}$ & $8.84 \mathrm{a}$ \\
\hline Lisophos +Potassium Sulphate & $15.20 \mathrm{a}$ & $0.79 \mathrm{c}$ & $15.50 \mathrm{a}$ & $0.76 \mathrm{c}$ & $19.24 \mathrm{a}$ & $9.15 \mathrm{a}$ & $20.32 \mathrm{a}$ & $10.14 \mathrm{a}$ & $5.85 \mathrm{c}$ & $5.89 \mathrm{c}$ \\
\hline Lisophos + Calcium Sulphate & $14.50 \mathrm{~b}$ & $0.93 \mathrm{~b}$ & $14.60 \mathrm{c}$ & $0.88 \mathrm{~b}$ & $15.47 \mathrm{~b}$ & $8.77 \mathrm{~b}$ & $16.51 \mathrm{c}$ & $9.43 \mathrm{e}$ & $9.10 \mathrm{a}$ & $9.04 \mathrm{a}$ \\
\hline Potassium Sulphate + Calcium Sulphate & $14.40 \mathrm{~b}$ & $0.99 \mathrm{a}$ & $14.70 \mathrm{c}$ & $0.98 \mathrm{a}$ & $14.53 \mathrm{c}$ & $8.57 \mathrm{c}$ & $15.04 \mathrm{~d}$ & $9.63 \mathrm{~d}$ & $7.35 \mathrm{~b}$ & $6.37 \mathrm{c}$ \\
\hline
\end{tabular}

*Values, within each column, of similar letter (s) were not significantly different according to the least significant difference (LSD) at 0.05 levels.

At the meantime, there was a significant in anthocyanin content in the apple skins by all used treatments except the application of calcium sulphate at $2 \%(\mathrm{w} / \mathrm{v})$, relative to the control in both seasons. Meanwhile, the application of lisophos plus potassium sulphate resulted in a significant increase in anthocyanin formation followed by the sole treatment of potassium sulphate in a consistent manner. The application of lisophos alone was able to significantly increase anthocyanin in apples, such increase was higher than that obtained by its combination with calcium sulphate. Thus, it was evident that calcium sulphate had an influence on coloration of apples (Table 5). Moreover, chlo- rophyll a in fruit skin was at the highest content in the control and in calcium sulphate treated fruits that did not differ significantly in their chlorophyll a content. Meanwhile, many used treatments were able to reduce chlorophyll a content in apple skins especially with the application of the combination of lisophos plus potassium sulphate followed by the individual application of potassium sulphate. The presence of calcium sulphate along with lisophos or even plus potassium sulphate caused an increase in chlorophyll a content in the skin of fruits. Similar trends of results were obtained with chlorophyll $b$ since the greatest content was found in the control fruits especially 
in the second season, however, the combination of lisophos plus either potassium sulphate or calcium sulphate had an equal effect on chlorophyll $b$ and had similar content to that obtained in the control fruits. Thus, the consistent reduction in chlorophyll $b$ was only obtained with the application of potassium sulphate relative to the control. With regard to carotene content in fruit skin at harvest, it was found that there was a significant increase in carotene by the application of the combination of lisophos plus potassium sulphate in addition to the application of each compound individually. However, the application of calcium sulphate alone caused a significant reduction in carotene content while when it was applied along with potassium sulphate resulted in a slight increase in carotenes as compared with the control (Table 5).

Table 5. Effect of pre-harvest treatments of lisophos, potassium sulphate and calcium sulphate on skin pigments of "Anna" apples during 2016 and 2017, seasons.

\begin{tabular}{|c|c|c|c|c|c|c|c|c|}
\hline \multirow[b]{2}{*}{ Treatments } & \multicolumn{2}{|c|}{ Season 2016} & \multicolumn{2}{|c|}{ Season 2017} & \multicolumn{2}{|c|}{ Season 2016} & \multicolumn{2}{|c|}{ Season 2017} \\
\hline & $\begin{array}{c}\text { Anthocyanin } \\
\mathrm{mg} / \mathrm{100g}\end{array}$ & $\begin{array}{c}\text { Chlorophyll } \\
\text { a } \\
\mathrm{mg} / \mathbf{1 0 0 g}\end{array}$ & $\underset{\mathrm{mg} / \mathrm{100g}}{\text { Anthocyanin }}$ & $\begin{array}{c}\text { Chlorophyll } \\
\text { a } \\
\mathrm{mg} / 100 \mathrm{~g}\end{array}$ & $\begin{array}{c}\text { Chlorophyll } \\
\text { b } \\
\mathrm{mg} / \mathbf{1 0 0 g}\end{array}$ & $\begin{array}{l}\text { Carotene } \\
\mathrm{mg} / 100 \mathrm{~g}\end{array}$ & $\begin{array}{c}\text { Chlorophyll } \\
\text { b } \\
\mathrm{mg} / 100 \mathrm{~g}\end{array}$ & $\begin{array}{l}\text { Carotene } \\
\mathrm{mg} / \mathrm{100g}\end{array}$ \\
\hline Control (water only) & & $2.52 \mathrm{a}$ & $6.27 \mathrm{e}$ & $2.55 \mathrm{a}$ & $1.23 \mathrm{c}$ & 0.50 ef & $1.26 \mathrm{a}$ & $0.47 \mathrm{e}$ \\
\hline Lisophos at $1000 \mathrm{mg} / \mathrm{L}$ & $\mathrm{c}$ & & & & & & & $2 \mathrm{~b}$ \\
\hline Potassium Sulphate (PS) at 2\% & $13.11 \mathrm{~b}$ & & $12.62 \mathrm{~b}$ & 1.8 & $1.26 \mathrm{ab}$ & & $1.18 \mathrm{c}$ & $9 \mathrm{a}$ \\
\hline Calcium Sulphate (CS) at $2 \%$ & $6.20 \mathrm{e}$ & $4 \mathrm{a}$ & $6.49 \mathrm{e}$ & $2.57 \mathrm{a}$ & $1.24 \mathrm{abc}$ & $9 \mathrm{f}$ & $1.25 \mathrm{a}$ & $0.47 \mathrm{e}$ \\
\hline Lisophos +Potassium Sulphate & $14.18 \mathrm{a}$ & $1.83 \mathrm{f}$ & $13.90 \mathrm{a}$ & $1.88 \mathrm{~d}$ & $1.24 \mathrm{abc}$ & $0.67 \mathrm{a}$ & $1.24 \mathrm{ab}$ & $0.69 \mathrm{a}$ \\
\hline Lisophos + Calcium Sulphate & $7.41 \mathrm{~d}$ & $2.41 \mathrm{~b}$ & $8.41 \mathrm{~d}$ & $2.46 \mathrm{~b}$ & $1.27 \mathrm{a}$ & $0.51 \mathrm{e}$ & $1.21 \mathrm{bc}$ & $0.54 \mathrm{~d}$ \\
\hline Potassium Sulphate + Calcium Sulphate & $8.84 \mathrm{c}$ & $2.38 \mathrm{c}$ & $8.48 \mathrm{~d}$ & $2.45 \mathrm{~b}$ & $1.25 \mathrm{abc}$ & $0.54 \mathrm{~d}$ & $1.21 \mathrm{bc}$ & $0.57 \mathrm{c}$ \\
\hline
\end{tabular}

*Values, within each column, of similar letter (s) were not significantly different according to the least significant difference (LSD) at 0.05 levels.

\section{Post-harvest fruit assessment:}

The data in (Table 6) provided evidence that it was possible to significantly reduce the incidence of soft scald percentage (Table 6) in the fruit by many used treatments. Such percentage in the control fruits ranged between $30 \%$ to more than $36 \%$ while in calcium-treated fruits, the incidence of soft scald ranged between $11 \%$ to $16 \%$ whether calcium sulphate was applied alone or in combination with lisophos. Meanwhile, incidence of the soft scald with the use of lisophos alone at $1000 \mathrm{ppm}$ was also very effective on reducing soft scald formation in apple fruits. Furthermore, the application of potassium sulphate alone or in combina- tion with calcium sulphate had an equal influence on reducing incidence of the soft scald in apples. Moreover, the application of lisophos plus potassium sulphate that had a significant influence on skin coloration was also effective on reducing the disorder of soft scald as compared with the control (Table 6). With regard to the response of flesh firmness to various applied treatments, the data in Table 6 revealed that even with the successful reduction of soft scald and the enhancement of coloration and skin tissues by many treatments, three was either an increase in flesh firmness caused by the combination of lisophos plus calcium sulphate or even the individual use of either one espe- 
cially in the second season relative to the control. Moreover, lisophos plus potassium did not reduce flesh firmness in spite of its frequent-positive effects on color improvement and soft scald incidence (Table 6). Concerning the effect of various treatments on weight loss percentage after harvest, the data indicated that "Anna" apples had the least significant loss when was treated with either lisophos alone or lisophos combination with calcium sulphate in both seasons. The highest weight loss was found with the control fruit. However, several treatments resulted in similar weight loss percentage to that found in the control especially in the first season such as potassium alone or in combination with lisophos in addition to potassium sulphate plus calcium sulphate. Moreover, calcium sulphate alone was able to consistently reduce weight loss in both seasons relative to the control.

Table 6. Effect of pre-harvest treatments of lisophos, potassium sulphate and calcium sulphate on soft scald percentage, flesh firmness and weight lossof "Anna" apples after storage during 2016 and 2017, seasons.

\begin{tabular}{|c|c|c|c|c|c|c|}
\hline \multirow{2}{*}{ Treatments } & \multicolumn{2}{|c|}{ Season 2016} & \multicolumn{2}{|c|}{ Season 2017} & \multirow{2}{*}{$\begin{array}{c}\begin{array}{c}\text { Season } \\
2016\end{array} \\
\text { Weight } \\
\text { loss \% } \\
\end{array}$} & \multirow{2}{*}{$\begin{array}{c}\begin{array}{c}\text { Season } \\
2017\end{array} \\
\text { Weight } \\
\text { loss \% }\end{array}$} \\
\hline & $\begin{array}{c}\text { Soft scald } \\
\%\end{array}$ & $\begin{array}{c}\text { Firmness } \\
\left.\text { (Ib/ inch }^{2}\right)\end{array}$ & $\begin{array}{c}\text { Soft scald } \\
\%\end{array}$ & $\begin{array}{l}\text { Firmness } \\
\left(^{\left(I b / \text { inch }^{2}\right)}\right.\end{array}$ & & \\
\hline Control (water only) & $30.00 \mathrm{a}$ & $7.90 \mathrm{~b}$ & $36.67 \mathrm{a}$ & $7.37 \mathrm{~d}$ & $5.00 \mathrm{a}$ & $5.67 \mathrm{a}$ \\
\hline Lisophos at $1000 \mathrm{mg} / \mathrm{L}$ & $15.00 \mathrm{bc}$ & $8.00 \mathrm{~b}$ & $21.67 \mathrm{bc}$ & $7.53 \mathrm{bc}$ & $2.83 \mathrm{~b}$ & $3.17 \mathrm{~d}$ \\
\hline Potassium Sulphate (PS) at $2 \%$ & $18.33 \mathrm{~b}$ & $7.53 \mathrm{c}$ & $25.00 \mathrm{~b}$ & $7.13 \mathrm{e}$ & $4.67 \mathrm{a}$ & $5.17 \mathrm{~b}$ \\
\hline Calcium Sulphate $(\mathrm{CS})$ at $2 \%$ & $11.67 \mathrm{c}$ & $8.10 \mathrm{ab}$ & $16.67 \mathrm{c}$ & $7.57 \mathrm{bc}$ & $2.67 \mathrm{~b}$ & $3.33 \mathrm{~d}$ \\
\hline Lisophos +Potassium Sulphate & $16.67 \mathrm{~b}$ & $7.90 \mathrm{~b}$ & $20.00 \mathrm{bc}$ & $7.40 \mathrm{~cd}$ & $4.33 \mathrm{a}$ & $4.67 \mathrm{c}$ \\
\hline Lisophos + Calcium Sulphate & $11.67 \mathrm{c}$ & $8.30 \mathrm{a}$ & $16.67 \mathrm{c}$ & $7.83 \mathrm{a}$ & $2.50 \mathrm{~b}$ & $3.00 \mathrm{~d}$ \\
\hline Potassium Sulphate + Calcium Sulphate & $16.67 \mathrm{~b}$ & $7.90 \mathrm{~b}$ & $21.67 \mathrm{bc}$ & $7.33 \mathrm{~d}$ & $4.13 \mathrm{a}$ & $4.53 \mathrm{c}$ \\
\hline
\end{tabular}

*Values, within each column, of similar letter (s) were not significantly different according to the least significant difference (LSD) at 0.05 levels.

Some fruit parameters were also assessed after harvest (Table 7) in relation to preharvest treatments, the data of total soluble solids percentage (TSS) indicated that all applied treatments before harvest resulted in a significant increase TSS after harvest but varied in the magnitude of such increase. For example, the greatest increase in TSS was obtained with the applications of either lisophos plus potassium sulphate, followed by potassium sulphate alone, then lisophos at $1000 \mathrm{ppm}$. On the other hand, juice acidity was the highest at the control fruits in both seasons, and was similar to that acidity resuting from the application of calcium sulphate alone. Moreover, the least juice acidity of "Anna" apples was obtained with potassium sulphate alone or when was combined with lisophos. The application of lisophos alone at $1000 \mathrm{ppm}$ resulted also in reducing juice acidity when compared with the control. The changes in the TSS to acidity ratios were also influenced by various applied treatments prior harvest (Table 7). The data provided more evidence that the increase in TSS to acidity by lisophos plus potassium sulphate as well as potassium sulphate alone. However, calcium sulphate alone was as effective as the 
control. Furthermore, there were many other treatments that were equally effective on TSS to acidity ratio such as lisophos alone, lisophos plus calcium sulphate in addition to potassium sulphate plus calcium sulphate. The data in Table 6 also showed the changes in anthocyanin content after harvest in response to applied treatment before harvest, this data indicated that the greatest increase in anthocyanin was obtained with potassium sulphate alone or when was applied in combination with lisophos. The sole application of lisophos at $1000 \mathrm{ppm}$ was also able to increase anthocyanin content after harvest. However, the opposite trend was found with the application of calcium sulphate since there was less anthocyanin in the fruit relative to the control. Moreover the combination of lisophos plus calcium sulphate did not increase anthocyanin in the second season.

Table 7. Effect of pre-harvest treatments of lisophos, potassium sulphate and calcium sulphate on some chemical characteristics of "Anna" apples after storage during 2016 and 2017, seasons.

\begin{tabular}{|l|c|c|c|c|c|c|c|c|}
\hline \multirow{2}{*}{ Treatments } & \multicolumn{2}{|c|}{ Season 2016 } & \multicolumn{2}{c|}{ Season $\mathbf{2 0 1 7}$} & \multicolumn{2}{c|}{ Season 2016 } & \multicolumn{2}{c|}{ Season 2017 } \\
\cline { 2 - 8 } & TSS \% & $\begin{array}{c}\text { Acidity } \\
\mathbf{\%}\end{array}$ & TSS \% & $\begin{array}{c}\text { Acidity } \\
\mathbf{\%}\end{array}$ & $\begin{array}{c}\text { TSS/ } \\
\text { acidity } \\
\mathbf{\%}\end{array}$ & $\begin{array}{c}\text { Anthocyanin } \\
\mathbf{m g} / \mathbf{1 0 0 g}\end{array}$ & $\begin{array}{c}\text { TSS/ } \\
\text { acidity } \\
\mathbf{\%}\end{array}$ & $\begin{array}{c}\text { Anthocyanin } \\
\mathbf{m g} / \mathbf{1 0 0 g}\end{array}$ \\
\hline Control (water only) & $13.70 \mathrm{f}$ & $0.95 \mathrm{a}$ & $13.60 \mathrm{f}$ & $0.94 \mathrm{a}$ & $14.40 \mathrm{c}$ & $8.70 \mathrm{~d}$ & $13.72 \mathrm{c}$ & $8.98 \mathrm{~d}$ \\
\hline Lisophos at 1000 mg/L & $15.00 \mathrm{bc}$ & $0.85 \mathrm{~b}$ & $14.70 \mathrm{bc}$ & $0.87 \mathrm{~b}$ & $17.50 \mathrm{~b}$ & $10.84 \mathrm{~b}$ & $16.88 \mathrm{~b}$ & $10.91 \mathrm{c}$ \\
\hline Potassium Sulphate (PS) at 2\% & $15.30 \mathrm{ab}$ & $0.75 \mathrm{~d}$ & $14.90 \mathrm{ab}$ & $0.79 \mathrm{~d}$ & $20.40 \mathrm{a}$ & $15.18 \mathrm{a}$ & $18.86 \mathrm{a}$ & $15.68 \mathrm{~b}$ \\
\hline Calcium Sulphate (CS) at 2\% & $14.20 \mathrm{e}$ & $0.93 \mathrm{a}$ & $13.90 \mathrm{e}$ & $0.98 \mathrm{a}$ & $15.40 \mathrm{c}$ & $8.20 \mathrm{e}$ & $14.21 \mathrm{c}$ & $7.63 \mathrm{e}$ \\
\hline Lisophos +Potassium Sulphate & $15.40 \mathrm{a}$ & $0.79 \mathrm{~cd}$ & $15.10 \mathrm{a}$ & $0.80 \mathrm{~cd}$ & $19.49 \mathrm{a}$ & $15.04 \mathrm{a}$ & $18.78 \mathrm{a}$ & $16.11 \mathrm{a}$ \\
\hline Lisophos + Calcium Sulphate & $14.70 \mathrm{~cd}$ & $0.83 \mathrm{bc}$ & $14.60 \mathrm{c}$ & $0.87 \mathrm{~b}$ & $17.71 \mathrm{~b}$ & $9.77 \mathrm{c}$ & $16.77 \mathrm{~b}$ & $9.13 \mathrm{~d}$ \\
\hline Potassium Sulphate + Calcium Sulphate & $14.60 \mathrm{~d}$ & $0.85 \mathrm{~b}$ & $14.30 \mathrm{~d}$ & $0.84 \mathrm{bc}$ & $17.03 \mathrm{~b}$ & $10.05 \mathrm{c}$ & $16.94 \mathrm{~b}$ & $9.27 \mathrm{~d}$ \\
\hline
\end{tabular}

*Values, within each column, of similar letter (s) were not significantly different according to the least significant difference (LSD) at 0.05 levels.

\section{Discussion}

Poor coloration and soft scald disorder determinate the value and the best prices of apples in market. Therefore, the present study provided evidence that it was possible to significantly reduce the incidence of soft scald and enhance coloration of apples by some preharvest treatments. According to the data in Table 2, the applications of lisophos, calcium sulphate, potassium sulphate and their combinations lowered the percentage of soft scald at harvest as compared with control treatment. The positive role of lisophos on reducing soft scald might be attributed to its influence on membrane integrity and in- hibited the enzyme activity leads to cell wall and membrane breakdown which reflects on reducing the physiological disorders (Farag and Palta, 1993; Ryu et al., 1997). Attia and Farag, 2017 indicated that preharvest spray of either lisophos or $\mathrm{CaCl}_{2}$ reduced water berry physiological disorder in Thompson seedless table grapes. Also, the positive effect of calcium on reducing soft scald disorder could be attributed to their effect on reducing softening and senescence of fruits (Barker and Pilbeam, 2007). In contrary, calcium deficiency causes bitter pit disorder in apples (Kader, 2002). Furthermore, preharvest application of potassium 
reduced internal browning disorder in pineapple fruit (Soares, 2005).

To explain the role of lisophos on apple fruit firmness, Farag and Attia, 2016 showed that preharvest spray of lisophos on plum fruit trees increased fruit firmness at harvest and keeping storability during storage. In the present study, lisophos spray showed positive effects on increasing fruit firmness (Table 2). Rato et al. (2004) found that plum fruits with higher calcium content showed higher firmness and lower ethylene production rates as compared with fruits with lower calcium content. The results of current study agreed with those obtained by (Roy, 1995, Jaleel et al., 2007 and Bhat et al., 2012). On the other hand, potassium fertilization negatively affected flesh firmness as a result of their expanded cell walls and smaller proportion of cell wall materials in relation to their total volume (Nava et al. 2007).

The data in Table 3 revealed that there was no significant alteration in some physical characteristics of Anna apples by preharvest treatments except with the application of potassium sulphte on fruit diameter. The non-significant effect of mentioned treatments could be attributed to the time of application after the completion of fruit growth. The positive effects of potassium on fruit diameter found in this study might be attributed to enhance formation and translocation of carbohydrates and osmoregulation which in turn improved fruit quality (White and Karley, 2010). Also, enhances cell hydration and its deficiency causes tissue dehydration (Menzel and Kirby, 2001). The results of present study agreed with those obtained by Divya Pandey, 2016 on Litchi fruit and Anjum et al. 2008 on apple fruit. The decrease in fruit TSS and total sugars found in this study caused by preharvest application of calcium agreed with the findings of others such as Attia, 2017 on pomegranates, Attia and Farag, 2017 on grapes and Attia, 2009 on apricot. They all found that calcium-treated fruits reduced TSS, total sugars and increased fruit acidity. Meanwhile, potassium foliar application increased TSS, total sugars and reduced acidity (Table 4).Foliar application of potassium improved TSS content due to its role in translocation of sugar from leaves to fruits, which resulted in better quality fruits in apple (Shirzadeh and Kazemi, 2012). These trends of results are in harmony with the findings of Anjum et al. 2008 on apple, Chanana and Gill, 2008 on grapes and Dutta and Banik, 2007 on guava.

There was a significant increase in anthocyanin content in apple skins by all used treatments except the application of calcium sulphate as compared with control treatment (Table 5). The positive effect of lisophos on anthocyanin formation was previously reported (Farag and Attia, 2016, 2017; Ozgen et al., 2015). The positive effects might be attributed to enhance ethylene production, carotenoid accumulation and enhance coloration enzymes such as (phenylalanine ammonium lyase, 1aminocycloprpopane1-carboxylic acid and insoluble acid invertase) (Hong et al., 2008; Farag and Palta, 1989 and Ozgen, 2004). Also, potassium treatment enhanced coloration of apples. Lester et al. (2005) ob- 
served that improvement of fruit color with potassium is attributed to their effects on carbohydrate influx as optimum $\mathrm{K}$ level enhanced phloem loading, nutrient transportation and unloading of sucrose. In addition potassium might be important in the anthocyanin pathway and could be a cofactor in the activation of some specific enzymes (Hunsche and Ernani, 2003). The positive effect of potassium on fruit coloration was previously reported on Nectarines (Yang et al., 2008) and on apple (EL-Gazzar, 2000). On the other hand, the present study showed that calcium treatment retard coloration of apples. These results were in agreement with Attia and Farag, 2017 on grapes and Attia, 2009 on apricots.

The data in Table 6 illustrated that it was possible to reduce the incidence of soft scald after storage also keeping fruit firmness and reducing weight loss of apples which reflects on keeping fruit quality after storage. The use of lisophos and calcium inhibited ethylene production in ripening fruits and maintain fruit firmness which reflects on extend apples shelf life (Hong, 2006). Also, retards the activity of enzymes such as polygalactourenase which reflect on retarding the cell wall hydrolysis (Wehr et al., 2004; Bhat et al., 2012). Kou et al. (2015) treated pear with $\mathrm{CaCl}_{2} 2 \%$ inhibited the development of brown spots on 'Huangguan' pear by delaying the loss of the polyphenol substances (inhibited the activities of polyphenol-oxidase and peroxidase, increased the activities of catalase and superoxide dismutase) and maintaining the structural integrity of cell membrane.
References

A.O.A.C. (1985). Official Methods of Analysis of the Association of Official Analytical Chemists. Washington D C, USA, $14^{\text {th }} \mathrm{Ed}$.

Anjum, R., Kirmani, N. A., Nageena, N., and Sameera, S. (2008). Quality of apple cv. Red delicious as influenced by potassium. Asian Journal of Soil Science, 3(2), 227-229.

Atkinson, R. G., Bolitho, K. M., Wright, M. A., Iturriagagoitia-Bueno, T., Reid, S. J., and Ross, G. S. (1998). Apple ACC-oxidase and polygalacturonase: ripening specific gene expression and promoter analysis in transgenic tomato. Plant Molecular Biology 38: 449-460.

Attia, S. M. (2009). Effect of some preharvest treatments on quality and ripening of "Canino" apricot fruits and on their shelf life. MSc. Faculty of Agriculture- Damanhour Branch- Alexandria University, Egypt.

Attia, S. M. (2017). Manipulation of splitting, sunburn and enhancing coloration of "Wonderful" pomegranates by preharvest foliar applications. IJRDO-Journal of Agriculture and Research. Vol. 3(5): 1 -9.

Attia, S. M and Karim M. Farag.(2017). Effect of Some Preharvest Treatments on the Incidence of Waterberry Disorder and on Fruit Quality Characteristics of "Thompson seedless" Table Grapes. AmericanEurasian J. Agric. \& Environ. Sci., 17 (5): 392-400.DOI: 10.5829/idosi.aejaes. 2017.392.400.

Barker, A.V., and Pilbeam, D.J., (2007). Handbook of Plant Nutrition. CRC Press, Boca Raton, FL.

Bhat, M., Ahsan, H., Banday, F., Dar, M., Wani, A.I., and Hassan, G., (2012). Effect of harvest dates, preharvest calcium sprays and storage period on physicochemical 
characteristics of pear cv. Bartlett. J. Agric. Res. Dev. 2, 101-106.

Boyer, J. and Liu, R. (2004). Apple phytochemicals and their health benefits.Nutr. J. 3, 5.

Bramlage, W.J. (1993). Interactions of orchard factors and mineral nutrition on quality of pome fruit.Acta Hort. 326: 15-28.

Chanana, Y. R and Gill M. I. S. (2008). High quality grapes can be produced in Punjab. ActaHort785: 8586.

DeEll, J.R. (2009). Storage Disorders of Apples. Storage control systems Inc. On line [http://www.storagecontrol.com/do cuments/Storage\%20Disorders\%20of $\% 20$ Apple s.pdf].Consulted on March $15^{\text {th }} 2010$.

DivyaPandey, (2016). Effect of foliar application of $\mathrm{KNO} 3$ on fruit yield and quality in litchi. MSc. Punjab Agricultural University, Ludhiana - 141004, Punjab, India.

Dutta and Banik A. K. (2007). Effect of Foliar feeding of nutrients and plant growth regulators on physico-chemical quality of Sardar Guava grown in red and lateritic tract of West Bengal. ActaHort 735: 407-12.

Egan, H., Kirk, R. S and Sawyer, R. (1981). Pearson's chemical analysis of food: Churchill Livingstone, Edinburgh London, Melbourne and New York, pp591.

El-Gazzar, A. A. M.(2000). Effect of fertilization with nitrogen, potassium and magnesium on Anna apples. 1. Effect of nitrogen fertilization. Annals AgricSci (Cairo) 3: $1145-52$.

Emongor, V.E., Murr, D.P., and Lougheed, E.C., (1994). Preharvest factors the predispose apples to superficial scald. Postharv. Biol. Technol. 4, 289-300.
Farag, K.M. and J.P. Palta. (1989). Stimulation of ethylene production by urea, thidiazuron and lysophosphatidylethanolamine and possible sites of stimulation. Plant Physiol. 89:568 (Abstr.).

Farag, K.M. and J.P. Palta. (1992). Evidence for a specific inhibition of the activity of polygalacturonase by lysophosphatidylethanolamine in tomato fruit tissue: Implication for enhancing storage stability and reducing abscission of the fruit. Plant Physiol. 99:54 (Abstr.).

Farag, K.M. and J.P. Palta.(1993). Use of Natural Lipids to Accelerate Ripening and Enhance Storage Life of Tomato Fruit with and without Ethephon. HortTechnology 62-95.

Farag, K. M. (2006). Effect of Ethrel pH on the shelf life and incidence of scalding of "Anna" apple fruits. J. Agric. and Env. Sci. Alex. Univ., Egypt. Vol. 5 (1): 21-35.

Farag, K. M and Said M. Attia. (2016). Enhancing coloration and extending the shelf life of plums while alleviating leaf abscission by utilizing lysophosphatidylethanolamine and oleic acid. J. Plant Production, Mansoura Univ., Vol. 7 (7): 791 799.

Farag, K. M and Said M. Attia. (2017). Enhancing quality and prolonging the shelf life of preharvest-treated "Kelsey" plums by some natural compounds. J. Agric. and Env. Sci. Dam. Univ., Egypt. Vol. 16(1): 118.

Fuleki, T. and F. J. Francis., (1968). Quantitative methods for anthocyanins. 1- Extraction and determination of total anthocyanin in cranberries. Journal of Food Science, 33:72-77.

Gill, P. P. S, Ganaie M Y, Dhillon W S and Singh N. P. (2012). Effect of foliar sprays of potassium on fruit 
size and quality of Patharnakh' pear. Indian J Hort69: 512-16.

Glenn, G. M. and Poovaiah, B. W. (1990). Calcium-mediated postharvest changes in texture and cell wall structure and composition in 'Golden Delicious' apples. Journal of the American Society for Horticultural Science 115: 962-968.

Hong, J. H. (2006). Lysophosphatidylethanolamine Enhances Ripening and Prolongs Shelf Life in Tomato Fruit: Contrasting Effect on Mature Green vs Red Tomatoes.Korean Society for Horticultural Science. Vol.47 (2), 55-58.

Hong, J.H., S.K. Hwang, and G.H. Chung. (2008). Influence of lysophosphatidylethanolamine on reactive oxygen species, ethylene biosynthesis, and auxin action in plant tissue. Kor. J. Hort. Sci. Techol. 26:209-214.

Hunsche, M., Brackmann, A., and Ernani, P.R. (2003). Effects of K fertilization on the post-havest quality of 'Fuji' apples. Brazilian Journal of Agricultural Research, 38: 489496.

Jaleel, C.A., Manivannan, P., Sankar, B., Kishorekumar, A., Gopi, R., Somasundara and R., Panneerselvam, R., (2007). Water deficit stress mitigation by calcium chloride in Catharanthusroseus: effects on oxidative stress, proline metabolism and indole alkaloid accumulation. Colloids Surf. B: Biointerfaces 60, 110-116.

Johnston, J. W.; Hewett, E. W.; Hertog, M. L. A. T. M.; Harker, F. R. (2002a). Harvest date and fruit size affect postharvest apple softening. Journal of Horticultural Science and Biotechnology 77: 355-360.

Johnston, J. W.; Hewett, E. W.; Hertog, M. L. A. T. M. and Harker, F. R. (2002b). Temperature and ethylene affect induction of rapid softening in 'Granny Smith' and 'Pacific Rose" apple cultivars. Postharvest Biology and Technology 25: 257264.

Kader, A.A., (2002). Post-harvest Technology of Horticultural Crops, $3^{\text {rd }}$ ed. University of California, Oakland, California. Division of Agriculture and Natural Resources Publication 3311.

Kou, X., Wu, M., Li, L., Wang, S., Xue, Z., Liu, B., \& Fei, Y. (2015). Effects of $\mathrm{CaCl}_{2}$ dipping and pullulan coating on the development of brown spot on 'Huangguan' pears during cold storage. Postharvest biology and technology, 99, 63-72.

Lester, G. E, Jifon J L and Stewart W M. (2007). Foliar potassium improves cantaloupe marketable and nutritional quality. Better Crops 91: 2425.

Lichtenthaler, H.K., and A.R. Wellburn. (1985). Determination of total carotenoids and chlorophylls $\mathrm{a}$ and $\mathrm{b}$ of leaf in different solvents, Biol. Soc. Trans. 11: 591-592.

Menzel K and Kirby E A. (2001). Principles of Plant Nutrition.Pp 685.International Potash Institute, IPI, Bern, Switzerland.

Nava, G., Dechen, A. R., and Nachtigall, G. R. (2007). Nitrogen and potassium fertilization affect apple fruit quality in southern Brazil. Communications in Soil Science and Plant Analysis, 39(1-2), 96-107.

Özgen, M. (2004). Lysophosphatidylethanolamine accelerates color development and promotes shelf life of cranberries. HortScience 40:127-130.

Özgen, M.,SedatSerçe, Yaşar Akça, and JiHeun Hong. (2015). Lysophosphatidylethanolamine (LPE) improves fruit size, color, quality and phytochemical contents of sweet cherry cv. '0900 Ziraat'. Kor. J. Hort. Sci. Technol. 33(2):196-201. 
Rato, A. E., Marreiros, H. I., Santos, A. C., and Barroso, J. M. (2004). Effects of different fruit calcium levels on the postharvest physiology of plums (Prunusdomestica L.). In $\mathrm{V}$ International Postharvest Symposium 682 (pp. 171-176).

Roy , G. Gillen., (1995). Use secondary ion mass spectrometry to image calcium - UV uptake in the cell wall of apple Fruit. Protoplasma., $189: 163-172$.

Ryu, S.B., Karlsson, B.H., Özgen, M., Palta, J.P., (1997). Inhibition of phospholipase D by lysophosphatidylethanolamine, a lipidderived senescence retardant. Proc. Natl. Acad. Sci. 94, 12717-12721.

SAS, (2000). JMP: User's Guide, Version 4; SAS Institute, Inc.: Cary, NC, USA.

Schachtman, D. P and Shin R. (2007). Nutrient sensing and signaling: NPKS. Annu. Rev. Plant Biol. 58:47-69.

Shirzadeh, E and Kazemi M. (2012). Effect of Essential Oils Treatments on Quality Characteristics of Apple (Malusdomestica var. Gala) During Storage.Trends Applied Sci Res 7: 584-89.

Smith, F., (1956). Colorimetric method for determination of sugar and related substance. Analytical Chemistry; 28: 350-356.
Snedecor, G. W. and W. G. Cochran. (1980). Statistical Methods. $6^{\text {th }} \mathrm{Ed}$. Iowa State Univ. Press, Ames, Iowa. USA.

Snowdon, A.L. (1990). A Colour Atlas of Post-harvest Diseases \& Disorders of Fruits and Vegetables. Volume 1: General Introduction and Fruits. Wolfe Scienctific. London. 302 pages.

Soares, A. G., Trugo, L. C., Botrel, N., and da Silva Souza, L.F. (2005). Reduction of internal browning of pineapple fruit (Ananascomusus L.) by preharvest soil application of potassium. Postharvest Biology and Technology, 35(2), 201-207.

Wehr, J.B., Menzies, N.W., and Blamey, F.P.C., (2004). Inhibition of cellwall autolysis and pectin degradation by cations. Plant Physiol. Biochem. 42, 485-492.

White, P. J and Karley, A. J. (2010). Potassium. In Cell Biology of Metals and Nutrients, ed. R Hell, RR Mendel, pp. 199-224. Plant Cell Monogr. 17. Dordrecht: Springer.

Yang, Z. S, Jun Y and Hua, G. L. (2008). Effects of $\mathrm{K}$ nutrition levels on fruit quality of "Yanguang" nectarine. J Anhui AgricUniv35: 289-92. 
تقليل حدوث اللفحة الطرية وتحسين لون ثمار صنف التفاح الأنا بمعاملات ما قبل الجمع

\section{كريم محمد فرج و سعيد محمد عطية}

قسم البساتين (فاكهة)، كلية الزر اعة-جامعة دمنهور -مصر.

بالر غم من وجود العديد من العو امل و الظروف المرتبطة بحدوث مشكلة اللفحة الطريـة، الا

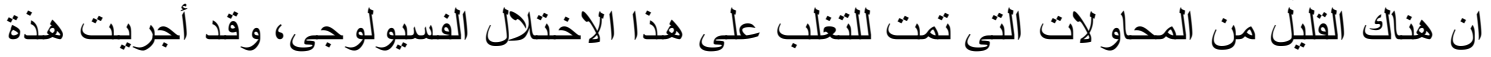

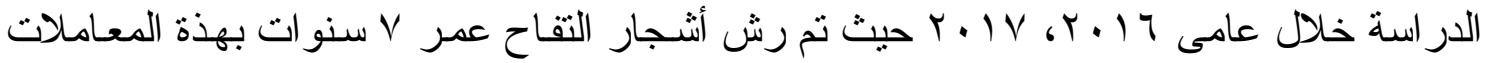

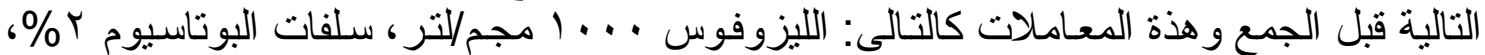

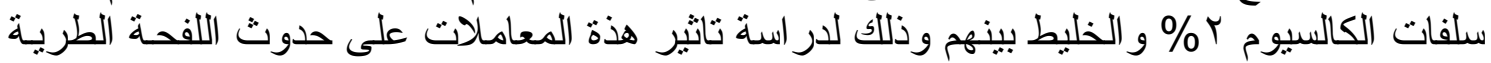

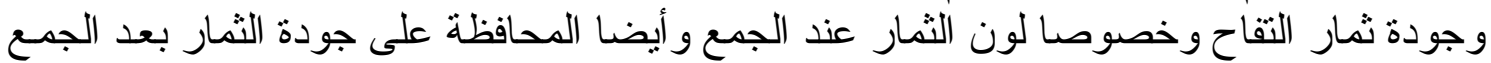

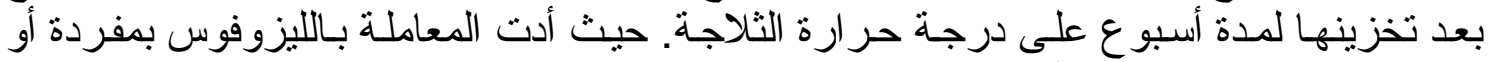

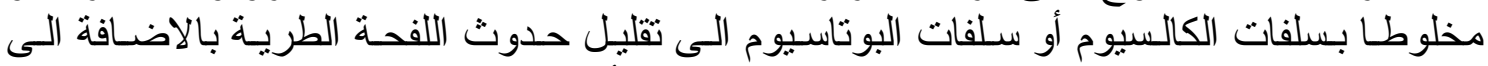
تاخير فقد صلابة الثمار عند الجمع مقارنة بالكنترول كما أدت المعاملة بسلفات البوتاسيوم بمفردهـا

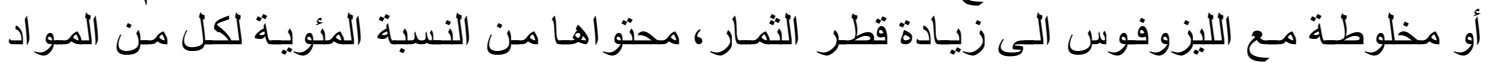

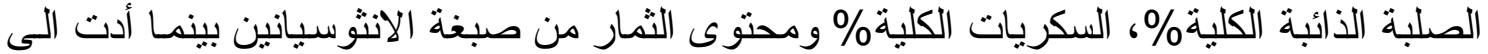

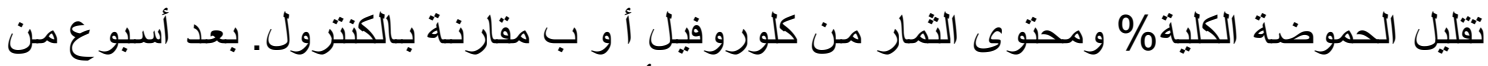

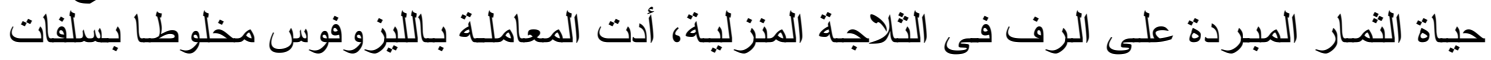

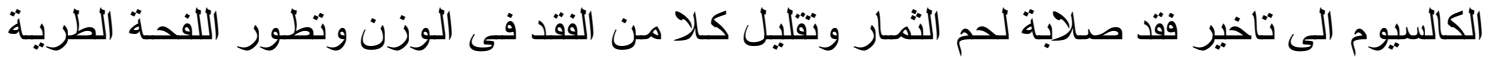

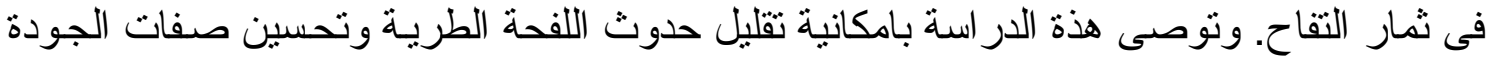
و اللون فى ثمار التفاح باستخدام الليزوفوس مخلوطا مـ سلفات الكالسيوم او سلفات البوناسيوم. 